Research Note

Journal of Extension Education

Vol. 31 No. 3, 2019

DOI:https://doi.org/10.26725/JEE.2019.3.31.6361-6368

\title{
A Scale to Measure Attitude of Farmers towards Agricultural Schemes for Sustainable Livelihood
}

\author{
E. Sathyapriya ${ }^{1}$ and M. Asokhan ${ }^{2}$
}

\begin{abstract}
Agriculture schemes are formulated to induce the agricultural growth of the nation and also improve the sustainable livelihood of the farming community. The study aims to develop a scale to measure the attitude of farmers towards agricultural schemes for sustainable livelihood of agrarians. Thurstone and Chave's (1929) equal appearing intervals scale method was adopted to develop the scale. The final scale comprised ten statements which are having universe of content, uniform distribution of scale values along the psychological continuum and high "scale values" and lower "Q" values and more or less equal number of favourable and unfavourable attitude items.
\end{abstract}

Keywords: Agriculture schemes; sustainable livelihood; equal appearing intervals scale; scale values; "Q" values

Agriculture and farmers are the backbone of India. However, agriculture's share in India's economy has progressively declined to less than 15.00 per cent. The major challenges in India are, nearly threequarters of India's families depend on rural incomes, and India's food security depends on producing cereal crops, as well as increasing its production of fruits, vegetables and milk to meet the demands of a growing population with rising incomes. To do so, a productive, competitive, diversified and sustainable agricultural sector will need to emerge at an accelerated pace, with this aim many of the agricultural schemes are formulated.
Hence, this research paper aims to develop the scale to measure the attitude of farmers towards the agricultural schemes for sustainable livelihood.

\section{METHODOLOGY}

The scale was constructed by following "Equal Appearing Interval" scaling technique developed by Thurstone and Chave (1929). For the purpose, attitude was operationalized as the degree of positive or negative affect of the farmers about agricultural schemes.

Possible statements concerning the pshychological object "agricultural schemes" were collected based on the review of literature

${ }^{1}$ Ph.D Scholar and ${ }^{2}$ Professor and Head, Dept. of Agricultural Extension and Rural Sociology, Tamil Nadu Agricultural University, Coimbatore-641 003.

Received : 29-02-2020; Accepted : 04-03-2020 
and discussion with scientists and from extension personnel. In total, 100 statements were prepared which were organized and structured in the form of attitude items. The items were screened by following the informal criteria suggested by Edwards (1969). Based on the screening, 82 items were selected which formed the universe of the content. The selected items includes both positive and negative statements.

The 82 statements were then subjected to judges opinion on a five-point continuum ranging from most unfavourableto most favourable. The items were screened by following the informal criteria suggested by Edwards (1969) for editing the statements to be used in the construction of the attitude scale. The list of statements was sent to 75 judges who comprised of scientists of state agricultural universities, ICAR and Krishivigyan Kendra. Among the 75 judges, 42 judges responded by sending their judgments. Based on the judgments the " $\mathrm{S}$ " and "Q"values for each statement were calculated by applying the equal appearing scale Interval formula as suggested by Thurstone and Chave (1929).

The $S$ value obtained from the following formula

$$
S=l+\left(\frac{0.5-\sum p_{b}}{p_{w}}\right) i
$$

S - The median or scale value of the statement

I - The lower limit of the interval in which the median falls

$\sum p_{b}$ The sum of the proportions below the interval in which the median falls $p_{w}{ }^{-}$The proportion within the interval in which the median falls

$\mathrm{i}$ - The width of the interval and is assumed to be equal to 1.0

Thurston and Chave(1929) used the interquartile range or $\mathrm{Q}$ as a measure of the variation of the distribution of judgments for a given statements. To determine the $\mathrm{Q}$ value, need to find two other point measures, the $75^{\text {th }}$ centile and the $25^{\text {th }}$ centile.

The $25^{\text {th }}$ Centile $\left(C_{25}\right)$ obtained from the following formula

$$
C_{25}=l+\left(\frac{0.25-\sum p_{b}}{p_{w}}\right) i
$$

The $75^{\text {th }}$ Centile $\left(C_{75}\right)$ obtained from the following formula

$$
C_{75}=l+\left(\frac{0.25-\sum p_{b}}{p_{w}}\right) i
$$

Inter quartile range (Q) value $=\mathrm{C}_{75}-\mathrm{C}_{25}$

\section{Scale Reliability}

Pearson's product moment correlation coefficient:

$$
\mathrm{r}_{\mathrm{xy}}=\frac{\sum \mathrm{xy}-\frac{\left(\sum \mathrm{x}\right)\left(\sum \mathrm{y}\right)}{\mathrm{n}}}{\sqrt{\left(\sum \mathrm{x}^{2}-\frac{\left(\sum \mathrm{x}\right)^{2}}{\mathrm{n}}\right) \times\left(\sum \mathrm{y}^{2}-\frac{\left(\sum \mathrm{y}\right)^{2}}{\mathrm{n}}\right)}}
$$

Where,

$\begin{array}{lll}\mathrm{N} & = & \text { Sample size } \\ \mathrm{X} & = & \text { Odd test } \\ \mathrm{Y} & = & \text { Even test }\end{array}$


A Scale to Measure Attitude of Farmers towards Agricultural Schemes for Sustainable Livelihood

$\Sigma x y-(\Sigma x)(\Sigma y) / n=\quad$ Sum of product of $x$ and $y$ $\sum x^{2}-\left(\sum x\right)^{2} / n=$ Sum of square of $x$ $\Sigma \mathrm{y} 2-(\Sigma \mathrm{y})^{2} / \mathrm{n}=\quad$ Sum of square of $\mathrm{y}$

Spearman-Brown Formula

Where,

$$
r_{t t}=\frac{2 r_{h h}}{1+r_{h h}}
$$

$r_{t t}$ - Reliability of a test estimated from reliability of one of its halves (Reliability coefficient of

the whole test)

$r_{h h}$ - Self correlation of a half test (Reliability coefficient of the half test)

\section{FINDINGS AND DISCUSSION}

Based on the calculation, Individual statements with " $\mathrm{S}$ " and "Q" values are presented in Table 1.

\section{Item selection}

The final attitude items were selected based on the universe of content, uniform distribution of scale values along the psychological continuum and high "scale values" and smaller "Q" values and more or less equal number of favourable and unfavourable attitude items. The scale values were arranged in descending order of magnitude and the difference between the successive scale values and the cumulative total of the computed differences were worked out. Since the selected scale values should have equal appearing interval and distributed uniformly along the psychological continuum it was necessary to form ten compartments so as to select ten statements with one statement from each of the compartment. The basis for forming the compartments was that, each compartment should be equally spaced in the continuum. For this purpose, the cumulative value (2.57) was divided by ten, which worked out to 0.257 and this formed the width of the first class interval. The second interval was worked out by adding the value with the width of the first class interval. Subsequently all the ten intervals were worked out.

\section{Ten Compartments}

\begin{tabular}{|l|l|l|}
\hline Compartment I & $:$ & 0.257 \\
\hline Compartment II & $:$ & $0.257+0.257=0.51$ \\
\hline Compartment III & $:$ & $0.514+0.257=0.771$ \\
\hline Compartment IV & $:$ & $0.771+0.257=1.028$ \\
\hline Compartment V & $:$ & $1.028+0.257=1.285$ \\
\hline Compartment VI & $:$ & $1.285+0.257 \quad=$ \\
& 1.542 \\
\hline Compartment VII & $:$ & $1.542+0.257=1.799$ \\
\hline Compartment VIII & $:$ & $1.799+0.257=2.056$ \\
\hline Compartment IX & $:$ & $2.056+0.257=2.313$ \\
\hline Compartment X & $:$ & $2.313+0.257=2.57$ \\
\hline
\end{tabular}

To select the attitude items from the ten compartments the "scale values" and the corresponding "Q" values were considered. Based on the criteria already mentioned items having high "scale values" and low "Q" values were selected with one item from each compartment. Care was taken to ensure that the selected items represented the universe of content and covered the different aspects of agricultural schemes. Thereby ten items were selected with equal appearing interval and with a uniform distribution along the psychological continuum. The attitude scale thus constructed is given in Table 2. 
Journal of Extension Education (Conference Special)

Table 1.

Computation of Equal Appearing Interval Scale

\begin{tabular}{|c|c|c|c|c|c|c|}
\hline $\begin{array}{c}\text { Statement } \\
\text { Number }\end{array}$ & Q Value & S Value & Difference & $\begin{array}{l}\text { Cumulative } \\
\text { frequency }\end{array}$ & $\begin{array}{c}\text { Equal appearing } \\
\text { class intervel }\end{array}$ & Compartments \\
\hline 71 & 3.33 & 0.14 & & & \multirow{14}{*}{0.26} & \multirow{14}{*}{ I } \\
\hline 2 & 1.48 & 0.29 & 0.14 & & & \\
\hline 7 & 2.07 & 0.29 & 0.00 & 0.14 & & \\
\hline 15 & 2.39 & 0.29 & 0.00 & 0.14 & & \\
\hline 18 & 1.75 & 0.29 & 0.00 & 0.14 & & \\
\hline 24 & 2.42 & 0.29 & 0.00 & 0.14 & & \\
\hline 32 & 1.07 & 0.29 & 0.00 & 0.14 & & \\
\hline 39 & 1.74 & 0.29 & 0.00 & 0.14 & & \\
\hline 42 & 2.40 & 0.29 & 0.00 & 0.14 & & \\
\hline 52 & 2.29 & 0.29 & 0.00 & 0.14 & & \\
\hline 61 & 1.57 & 0.29 & 0.00 & 0.14 & & \\
\hline 62 & 3.06 & 0.29 & 0.00 & 0.14 & & \\
\hline 65 & -0.11 & 0.29 & 0.00 & 0.14 & & \\
\hline 76 & 2.57 & 0.29 & 0.00 & 0.14 & & \\
\hline 16 & 2.50 & 0.50 & 0.21 & 0.36 & 0.51 & II \\
\hline 54 & 2.00 & 0.75 & 0.25 & 0.61 & \multirow{2}{*}{0.77} & \multirow{2}{*}{ III } \\
\hline 47 & 2.13 & 0.83 & 0.08 & 0.69 & & \\
\hline 6 & 2.10 & 1.00 & 0.17 & 0.86 & \multirow{16}{*}{1.03} & \multirow{16}{*}{ IV } \\
\hline 12 & 0.57 & 1.00 & 0.00 & 0.86 & & \\
\hline 23 & 2.70 & 1.00 & 0.00 & 0.86 & & \\
\hline 34 & 2.25 & 1.00 & 0.00 & 0.86 & & \\
\hline 35 & 3.65 & 1.00 & 0.00 & 0.86 & & \\
\hline 44 & 2.93 & 1.00 & 0.00 & 0.86 & & \\
\hline 45 & 2.51 & 1.00 & 0.00 & 0.86 & & \\
\hline 46 & 3.33 & 1.00 & 0.00 & 0.86 & & \\
\hline 57 & 2.08 & 1.00 & 0.00 & 0.86 & & \\
\hline 60 & 0.60 & 1.00 & 0.00 & 0.86 & & \\
\hline 63 & 2.33 & 1.00 & 0.00 & 0.86 & & \\
\hline 77 & 2.64 & 1.00 & 0.00 & 0.86 & & \\
\hline 79 & 1.75 & 1.00 & 0.00 & 0.86 & & \\
\hline 59 & 2.57 & 1.13 & 0.13 & 0.98 & & \\
\hline 38 & 3.89 & 1.14 & 0.02 & 1.00 & & \\
\hline 50 & 2.22 & 1.14 & 0.00 & 1.00 & & \\
\hline
\end{tabular}


A Scale to Measure Attitude of Farmers towards Agricultural Schemes for Sustainable Livelihood

\begin{tabular}{|c|c|c|c|c|c|c|}
\hline $\begin{array}{c}\text { Statement } \\
\text { Number }\end{array}$ & Q Value & S Value & Difference & \begin{tabular}{|l|} 
Cumulative \\
frequency
\end{tabular} & $\begin{array}{c}\text { Equal appearing } \\
\text { class intervel }\end{array}$ & Compartments \\
\hline 19 & 2.11 & 1.25 & 0.11 & 1.11 & \multirow{5}{*}{1.29} & \multirow{5}{*}{ V } \\
\hline 8 & 4.25 & 1.29 & 0.04 & 1.14 & & \\
\hline 82 & 1.75 & 1.33 & 0.05 & 1.19 & & \\
\hline 36 & 1.89 & 1.38 & 0.04 & 1.23 & & \\
\hline 37 & 2.13 & 1.38 & 0.00 & 1.23 & & \\
\hline 10 & 1.64 & 1.50 & 0.13 & 1.36 & \multirow{16}{*}{1.54} & \multirow{16}{*}{$\mathrm{VI}$} \\
\hline 11 & 0.76 & 1.50 & 0.00 & 1.36 & & \\
\hline 53 & 0.86 & 1.50 & 0.00 & 1.36 & & \\
\hline 55 & 2.29 & 1.50 & 0.00 & 1.36 & & \\
\hline 56 & 4.64 & 1.50 & 0.00 & 1.36 & & \\
\hline 66 & 0.09 & 1.50 & 0.00 & 1.36 & & \\
\hline 73 & 1.17 & 1.50 & 0.00 & 1.36 & & \\
\hline 27 & 2.60 & 1.56 & 0.06 & 1.41 & & \\
\hline 22 & 3.23 & 1.60 & 0.04 & 1.46 & & \\
\hline 28 & 1.29 & 1.60 & 0.00 & 1.46 & & \\
\hline 49 & 1.00 & 1.60 & 0.00 & 1.46 & & \\
\hline 14 & 2.40 & 1.63 & 0.02 & 1.48 & & \\
\hline 51 & 0.67 & 1.63 & 0.00 & 1.48 & & \\
\hline 3 & 1.56 & 1.67 & 0.04 & 1.52 & & \\
\hline 33 & 1.67 & 1.67 & 0.00 & 1.52 & & \\
\hline 67 & -0.33 & 1.67 & 0.00 & 1.52 & & \\
\hline 20 & 1.55 & 1.71 & 0.05 & 1.57 & \multirow{9}{*}{1.80} & \multirow{9}{*}{ VII } \\
\hline 70 & 1.42 & 1.71 & 0.00 & 1.57 & & \\
\hline 74 & 1.95 & 1.71 & 0.00 & 1.57 & & \\
\hline 40 & 8.36 & 1.78 & 0.06 & 1.63 & & \\
\hline 25 & 0.89 & 1.80 & 0.02 & 1.66 & & \\
\hline 29 & 4.83 & 1.80 & 0.00 & 1.66 & & \\
\hline 41 & 0.17 & 1.80 & 0.00 & 1.66 & & \\
\hline 43 & -1.45 & 1.82 & 0.02 & 1.68 & & \\
\hline 75 & 5.56 & 1.83 & 0.02 & 1.69 & & \\
\hline
\end{tabular}




\begin{tabular}{|c|c|c|c|c|c|c|}
\hline $\begin{array}{l}\text { Statement } \\
\text { Number }\end{array}$ & Q Value & S Value & Difference & $\begin{array}{l}\text { Cumulative } \\
\text { frequency }\end{array}$ & $\begin{array}{c}\text { Equal appearing } \\
\text { class intervel }\end{array}$ & Compartments \\
\hline 4 & 1.74 & 2.00 & 0.17 & 1.86 & \multirow{13}{*}{2.06} & \multirow{13}{*}{ VIII } \\
\hline 9 & -0.85 & 2.00 & 0.00 & 1.86 & & \\
\hline 13 & 4.52 & 2.00 & 0.00 & 1.86 & & \\
\hline 21 & 0.86 & 2.00 & 0.00 & 1.86 & & \\
\hline 26 & 1.15 & 2.00 & 0.00 & 1.86 & & \\
\hline 30 & 1.50 & 2.00 & 0.00 & 1.86 & & \\
\hline 31 & 1.39 & 2.00 & 0.00 & 1.86 & & \\
\hline 48 & 1.56 & 2.00 & 0.00 & 1.86 & & \\
\hline 58 & 1.82 & 2.00 & 0.00 & 1.86 & & \\
\hline 64 & -0.63 & 2.00 & 0.00 & 1.86 & & \\
\hline 68 & 5.00 & 2.00 & 0.00 & 1.86 & & \\
\hline 78 & 6.60 & 2.00 & 0.00 & 1.86 & & \\
\hline 69 & 3.89 & 2.17 & 0.17 & 2.02 & & \\
\hline 17 & 1.39 & 2.25 & 0.08 & 2.11 & \multirow{5}{*}{2.31} & \multirow{5}{*}{ IX } \\
\hline 80 & -1.33 & 2.40 & 0.15 & 2.26 & & \\
\hline 5 & -0.91 & 2.57 & 0.17 & 2.43 & & \\
\hline 81 & 0.83 & 2.60 & 0.03 & 2.46 & & \\
\hline 1 & 1.51 & 2.67 & 0.07 & 2.52 & & \\
\hline 72 & -1.71 & 2.71 & 0.05 & 2.57 & 2.57 & $x$ \\
\hline
\end{tabular}

\section{Scale Reliability}

The reliability of the scale was determined by 'split - half' method. The ten selected attitude items were divided into two equal halves by odd even method. The two halves were administered separately to 30 farmers in a non-sample area. The scores were subjected to product moment correlation test in order to find out the reliability of the halftest by using SPSS software. The half-test reliability coefficient ( $r$ ) was 0.585 which was significant at one per cent level of probability. Furtherthe reliability coefficient of the whole test was computed using the Spearman-Brown Prophecy formula. The whole test reliability $\left(r_{t t}\right)$ was 0.734 . When the purpose of the test is to compare the mean scores of two groups of narrowrange a reliability coefficient of 0.50 or 0.60 would suffice. Hence, the constructed scale is reliable as the reliable coefficient $\left(r_{t t}\right)$ was $>0.60$.

\section{Content Validity of the Scale}

Content validation was carried out by subjecting the selected ten items to judge's opinion.The judges were requested to indicate their presumed relevance to which the 
A Scale to Measure Attitude of Farmers towards Agricultural Schemes for Sustainable Livelihood

Table 2.

Selected Attitude Statements

\begin{tabular}{|c|l|c|c|c|}
\hline $\begin{array}{c}\text { Statement } \\
\text { No. }\end{array}$ & \multicolumn{1}{|c|}{ Statements } & Q Value & S Value & $\begin{array}{l}\text { Nature of the } \\
\text { statement }\end{array}$ \\
\hline 72 & $\begin{array}{l}\text { Effective promotional strategies strengthen } \\
\text { the farmers - extension relationship. }\end{array}$ & -1.71 & 2.71 & Favourable \\
\hline 80 & $\begin{array}{l}\text { Value addition schemes improve the economy } \\
\text { of farmers. }\end{array}$ & -1.33 & 2.40 & Favourable \\
\hline 9 & $\begin{array}{l}\text { Agricultural Minimum Support price is } \\
\text { encouraging the farmers to diversify to higher } \\
\text { value crops. }\end{array}$ & -0.85 & 2.00 & Favourable \\
\hline 43 & $\begin{array}{l}\text { Agricultural schemes are designed to } \\
\text { strengthen the complete value chain of the } \\
\text { agriculture. }\end{array}$ & -1.45 & 1.82 & Favourable \\
\hline 67 & $\begin{array}{l}\text { Agricultural schemes strengthen the technical } \\
\text { know- how among farming community. }\end{array}$ & -0.33 & 1.67 & Favourable \\
\hline 12 & $\begin{array}{l}\text { Adoption rate of new technologies increased } \\
\text { by agricultural schemes. }\end{array}$ & 0.57 & 1.00 & Favourable \\
\hline 65 & $\begin{array}{l}\text { Crop rotation practices are ensured by the } \\
\text { agricultural schemes. }\end{array}$ & -0.11 & 0.29 & Favourable \\
\hline 82 & $\begin{array}{l}\text { Farmers depend on agricultural schemes only } \\
\text { for incentives/subsidies. }\end{array}$ & 1.75 & 1.33 & Unfavourable \\
\hline 54 & $\begin{array}{l}\text { Agricultural schemes focus on gender } \\
\text { development instead of overall agricultural } \\
\text { development. }\end{array}$ & 2.00 & 0.75 & Unfavourable \\
\hline 16 & $\begin{array}{l}\text { Agriculturalschemessupport the development } \\
\text { of large scale enterprises alone. }\end{array}$ & 2.50 & 0.50 & Unfavourable \\
\hline
\end{tabular}

attitude items covered the different aspects of agricultural schemes. The responses were obtained on a four-point continuum of 'most adequately covered', 'more adequately covered', 'less adequately covered' and 'least adequately covered'. Scores of 4, 3, 2 and 1 were given for the points on the continuum respectively.
Totally 30 judges responded by sending their judgments. The mean score 2.5 was fixed as the basis for deciding the content validity of the scale. If the overall mean score of the attitude items as rated by the judges was above 2.5 the scale will be declared as valid and if not otherwise. In the present case the overall mean score was worked out as 
The scoring procedure is as follows,

\begin{tabular}{|l|c|c|c|c|c|}
\hline \multirow{2}{*}{$\begin{array}{c}\text { Nature of the } \\
\text { statement }\end{array}$} & $\begin{array}{c}\text { Strongly } \\
\text { Agree }\end{array}$ & Agree & Undecided & Disagree & $\begin{array}{c}\text { Strongly } \\
\text { disagree }\end{array}$ \\
\cline { 2 - 6 } $\begin{array}{l}\text { Positive } \\
\text { statements }\end{array}$ & 5 & 4 & 3 & 2 & 1 \\
\hline $\begin{array}{l}\text { Negative } \\
\text { statements }\end{array}$ & 1 & 2 & 3 & 4 & 5 \\
\hline
\end{tabular}

3.51 and therefore the constructed attitude scale is said to be valid.

\section{Administration of the Scale Value}

The ten attitude items selected were arranged randomly in order to avoid biased responses. The scale was administered on a five point continuum as strongly agree, agree, undecided, strongly disagree and disagree. The score obtained for each statement was summed up to arrive at the attitude score for the respondents. The score ranged from 50 (maximum) to 10 (minimum). Maximum score revealed a favourable attitude, while a minimum score indicated unfavourable attitude towards agricultural schemes for livelihood diversification. The responses were grouped as unfavourable, moderately favourable and highly favourable based on the cumulative frequency method.

The various methods available for constructing of an attitude scale, Equal Appearing Interval method scaling technique was used in this study to measure the attitude of farmers towards agricultural schemes. The scale would be highly useful to study the attitude on agricultural scheme by the farmers and other agriculture stakeholders.

\section{REFERENCES}

Edwards L. Allen, (1969). Techniques of attitude scale construction. Vakils, Feffer and Simons Private limited, Bombay, India, pp 83-117.

Thurstone \& Chave. (1929). The measurement of attitudes. Chicago University Press, Chicago, 97p. 